\title{
Characterisation of surface uptake and biosorption of cationic nuclear fission products by sulphate-reducing bacteria
}

\author{
Nonhlanhla Ngwenya' and Evans MN Chirwa'* \\ 'Water Utilisation Division, Department of Chemical Engineering, University of Pretoria, Pretoria 0002, South Africa
}

\begin{abstract}
The treatment of radioactive fission products $-{ }^{90} \mathrm{Sr}^{2+},{ }^{60} \mathrm{Co}^{2+}$ and ${ }^{137} \mathrm{Cs}^{+}$- from simulated nuclear wastewater was evaluated using locally-isolated sulphate-reducing organisms. In this study, sulphate-reducing bacteria (SRB) were used as biosorbents for removal of the cationic fission products. The cultures achieved $90 \%, 100 \%$, and $80 \%$ removal $\mathrm{of} \mathrm{Sr}^{2+}, \mathrm{Co}^{2+}$ and $\mathrm{Cs}^{+}$, respectively, for a $75 \mathrm{mg} \times \mathrm{e}^{-1}$ solution of each metal under a low ionic strength of $0.01 \mathrm{M}$. Increasing the ionic strength of the solution to 0.5 $\mathrm{M}$ resulted in a decreased metal uptake to $80 \%, 65 \%$ and $70 \% \mathrm{for}^{2+} \mathrm{Cr}^{2+} \mathrm{Co}^{2+}$ and $\mathrm{Cs}^{+}$, respectively. Approximately $68 \%$ of the adsorbed fraction on cell surfaces was exchangeable (i.e., was desorbed under acidic conditions). Using surface complexation models and equilibrium modelling analysis, reaction sites on the cell walls of the cultures were determined to belong to the $-\mathrm{COOH}$ and $-\mathrm{H}_{2} \mathrm{PO}_{4}$ groups ( $p K_{\mathrm{a}}=4-5$ and $7-8$, respectively). The distribution of the isoelectric equilibrium points for cell surfaces was consistent with the composition and characteristics of the identified microbial species in the culture which was dominated by the Gram(+ve) Bacilli - Lysinicibacillus boronitolerans AB199591 - and biofloc-forming Gram(-ve) SRBs, such as Desulfomonile tiedgei AF418162, Syntrophobacter wolinii X70905, and Desulforhopalus vacuolatus L42613. The high exchangeable fraction on the cells and the higher removal rates under lower ionic strength indicates that metal binding was non-electrostatic which was consistent with outer-sphere complexation behaviour.
\end{abstract}

Keywords: radionuclide recovery, surface complexation, sulphate-reducing bacteria, biosorption kinetics, bioremediation.

\section{INTRODUCTION}

The radioactivity in wastewater and sludge coming from nuclear fuel and radiochemical processing is mainly detected as a result of the presence of metallic fission products and transuranic elements in the wastewater stream. Among the troublesome elements are the lightweight fission products caesium (Ce-137), strontium (Sr-90) and cobalt (Co-60). These elements are characterised by very high mobility in water, high radiological decay rates and short half-lives. For example, strontium is highly mobile in both soils and groundwater systems (Dewiere et al., 2004) and has a half-life of 28 years (Chirwa, 2011). Although these elements are released in very small amounts compared to other waste compounds such as radiocarbon-14 (C-14), sodium and nitrate, their presence raises the radiation level enough for the whole bulk of the wastewater to be classified as low to medium level nuclear waste (LLW, MLW) (Greve et al., 2007). Such classification increases the cost of treatment and requires the disposal of the wastewater in specialized ponds with limited capacity.

The cationic fission products are easily taken up by plants and eventually enter the ecosystem through the food chain and mineral recycling (Ajlouni, 2007). Fission products are notorious for being chemically identical to benign and essential minerals such as potassium $\left(\mathrm{K}^{+}\right)$, magnesium $\left(\mathrm{Mg}^{2+}\right)$ and iron $\left(\mathrm{Fe}^{2+}\right)$. For example, the radioactive divalent cation strontium-90 $\left.{ }^{(90} \mathrm{Sr}^{2+}\right)$ is easily absorbed by vertebrates because, chemically, it resembles calcium $\left(\mathrm{Ca}^{2+}\right)$, which is a critical component of mammalian bone structure. In mammals, calcium is responsible for the bones' structural integrity and strength and is

\footnotetext{
To whom all correspondence should be addressed.

- +27 12 420-5894; Fax: +27 12 362-5089;

e-mail: Evans.Chirwa@up.ac.za

Received 23 March 2014; accepted in revised form 5 March 2015
}

therefore an essential component of the mammalian diet. After integrating into the bone matrix, Sr-90 continues to irradiate surrounding bone and muscle tissue resulting in bone sarcoma and leukaemia (Wohl et al., 2013). Due to such hazards, it is desirable to prevent the migration of water contaminated with nuclear radioisotopes into surface water and groundwater resources used as water supply sources.

Extensive research has been conducted on subsurface microbial interactions that relate to the chemistry and physical dynamics of radionuclide migration and remediation in geological systems (Kumar et al., 2007). Sulphate-reducing organisms (SROs) - also referred to as sulphate-reducing bacteria (SRB) - thrive in the deep aquifer environments typical of deep mines and geological nuclear waste repositories (Greve et al., 2007). Coincidentally, many sulphate-reducing organisms have been shown to possess unique properties on their cell walls that allow them to adsorb and retain metallic elements. The cells can thus be utilised in the adsorption of metallic fission products from radioactive wastewater (Chen et al., 2005; Ngwenya and Chirwa, 2010). The uptake of metallic species onto the surfaces of SROs can involve metabolic processes in living cells requiring energy dispersion or can occur as pseudo physicalchemical processes on the surfaces of dead biomass (Dewiere et al., 2004; Gadd, 2010).

During previous investigations, other researchers linked the adsorptive processes on bacterial cell walls to the presence of reactive functional groups on the bacterial cell surfaces (Vijayaraghavan and Yun, 2008; Zouboulis et al., 2004; Pagnanelli et al., 2006). Although attempts have been made to characterise the adsorption of metallic species on bacterial cell surfaces, there is still limited information on the actual role of the detected functional groups in facilitating metal uptake.

So far, adsorption of metallic species onto cell surfaces can be classified either as electrostatic (influenced by the charges of the adsorbent) or non-electrostatic, in which no charges are 
involved. Electrostatic models \{e.g., the constant capacitance model (CCM), diffuse layer model (DLM), and the triple layer model (TLM)\} contain at least one Coulombic correction factor to account for the effect of surface charge on surface complexation. These Coulombic correction factors take the form, $e^{-Z F \Psi_{i}} / R T$, where $Z=$ charge of the adsorbing ion, $F=$ Faraday constant $\left(\mathrm{C} \cdot \mathrm{molc}^{-1}\right), \Psi_{i}$ is the surface potential $(\mathrm{V})$ in the $i^{\text {th }}$ surface plane in the intrinsic conditional surface complexation constant expression, $R=$ molar gas constant $\left(\mathrm{J} \cdot \mathrm{gmol}^{-1} \times \mathrm{K}^{-1}\right)$, and $T=$ absolute temperature (K) (Goldberg, 1995). The voltage potential $(\mathrm{V})$ is calculated as a charge density per gram-mole per joule of energy spent $\left(\mathrm{C} \times \mathrm{J}^{-1} \cdot \mathrm{gmol}^{-1}\right)$ (Goldberg, 1995). The electrostatic model (EM) has been used successfully in relating surface charge to surface potential using arbitrarily assigned capacitance values to describe the electrostatic effect of metal adsorption onto bacterial surfaces (Ojeda et al., 2008).

In the CCM, the intrinsic discrete acidity constant of the reaction site is shifted, and its $\mathrm{pH}$ range of influence broadened, by the electrostatic potential, $\Psi$, at the so-called bacteria/water interface following the relationship shown in Eq. 1 (below):

$$
K_{\text {int }}=K_{\text {as }} \cdot e-\frac{E Z \Psi}{R T}
$$

where: $K_{\text {int }}=$ intrinsic stability constant referenced to zero surface charge and zero surface coverage, $K_{\text {as }}=$ stability constant at zero charge and zero surface coverage. In non-electrostatic models (NEMs), the surface charge equals zero and therefore $K_{\text {int }}$ in Eq. 1 is constant.

This study contributes knowledge on the SRB-radionuclide interaction by investigating the chemical nature of the SRB cell surface and how the structures on the cells react with $\mathrm{Sr}^{2+}$, $\mathrm{Co}^{2+}$ and $\mathrm{Cs}^{+}$in concentration ranges found in nuclear wastewater. The feasibility of an engineering process for removal and recovery of these elements depends on the nature of interaction between the elements and functional groups on the SRB cells. Although several studies have investigated the chemical structure and speciation of the functional groups on cell surfaces of several organisms (Liu et al., 2014; Borrok and Fein, 2005; Apell and Diller, 2002), the actual adsorption mechanism and how it can be affected by changing environmental conditions has not been investigated in detail. More specifically, the effect of co-precipitation of divalent species on the adsorption potential has not been reported.

\section{MATERIALS AND METHODS}

\section{Culture and medium}

An inoculum culture of SRB was supplied by a member of the Council for Scientific and Industrial Research (CSIR) (Pretoria, South Africa). The inoculum culture was originally collected from a deep coal mine and was maintained in the laboratoryscale semi-fed batch reactor under sulphate-reducing conditions. The original culture was assumed to be acclimated to low levels of radiation due to detected background uranium and other naturally-occurring radioactive materials (NORMs) at concentrations ranging from $110-170 \mu \mathrm{g} \cdot \mathrm{kg}^{-1}$ in coal mine soil samples. The bacteria were also expected to be tolerant to high salinity due to high levels of sulphate in the mine drainage water. The enrichment culture reactor was operated at a constant temperature of $35^{\circ} \mathrm{C}$ under continuous mixing.

The SRB culture was enriched in Butlin medium (Medium A), a liquid medium prepared by adding (in $1 \ell$ distilled water):
$5 \mathrm{~m} \ell$ sodium lactate ( $60 \%$ solution); $2.0 \mathrm{~g} \mathrm{MgSO}_{4} \cdot 7 \mathrm{H}_{2} \mathrm{O} ; 1.0 \mathrm{~g}$ $\mathrm{NH}_{4} \mathrm{Cl} ; 1.0 \mathrm{~g} \mathrm{CaSO}_{4} ; 0.5 \mathrm{~g} \mathrm{FeSO}_{4} \cdot\left(\mathrm{NH}_{4}\right)_{2} \mathrm{SO}_{4} \cdot 6 \mathrm{H}_{2} \mathrm{O} ; 1.0$ g yeast extract; $0.5 \mathrm{~g} \mathrm{~K}_{2} \mathrm{HPO}_{4}$; and $0.03 \mathrm{~g} \mathrm{Na}_{2} \mathrm{SO}_{3} \cdot 7 \mathrm{H}_{2} \mathrm{O}$ (Butlin et al., 1949). The enrichment procedure was repeated at least 3 times in order to obtain the desired concentration of metal-tolerant SRB species. The SRB cells obtained from the enrichment procedure were aseptically transferred to $1-\ell$ rubber-sealed batch anaerobic bioreactors and allowed to grow until midstationary phase (5-7 days). To optimise the culture for sulphate-reducing conditions, the cells were harvested from Medium A and transferred into a second growth medium, Postgate medium (Medium B), which was prepared by adding (in $1 \ell$ distilled water): $6 \mathrm{~m} \ell$ sodium lactate $(60 \%$ solution $\mathrm{w} / \mathrm{v})$; 1 g yeast extract; $1 \mathrm{~g} \mathrm{NH}_{4} \mathrm{CI} ; 4.5 \mathrm{~g} \mathrm{Na}_{2} \mathrm{SO}_{4} ; 0.5 \mathrm{~g} \mathrm{KH}_{2} \mathrm{PO}_{4} ; 0.06 \mathrm{~g}$ $\mathrm{MgSO}_{4} \cdot 7 \mathrm{H}_{2} \mathrm{O} ; 0.1 \mathrm{~g}$ sodium citrate $2 \mathrm{H}_{2} \mathrm{O} ; 0.06 \mathrm{~g} \mathrm{CaCI} \cdot 6 \mathrm{H}_{2} \mathrm{O}$; $0.1 \mathrm{~g}$ ascorbic acid; and $0.1 \mathrm{~g}$ sodium thioglycollate (Postgate, 1984). Cell activity was quantified by observing the reduction of sulphate and accumulation of sulphide in solution.

\section{Culture characterisation}

Colonies were developed on $9 \mathrm{~m} \ell$ solid medium prepared from Medium A converted to solid medium by adding $2.3 \%$ universal agar. $9 \mathrm{~m} \ell$ of the medium at $40^{\circ} \mathrm{C}$ was mixed with $1 \mathrm{~m} \ell$ of sample in a petri dish and allowed to solidify at room temperature. The plates were then incubated at $30^{\circ} \mathrm{C}$ in an anaerobic jar containing an Anaero Pack $\mathrm{O}_{2}$ Absorbing/ $\mathrm{CO}_{2}$ Generating System (Mitsubishi Gas Chemical Company, Inc., New York, New York, USA). After $24 \mathrm{~h}$, individual colonies were picked and cultured in a corresponding growth medium. The process of isolation was repeated 3 times to achieve a high degree of purity in the colonies. Transfers to petri dishes and all other open plate procedures were conducted in anaerobic glove bags purged with $99.9 \%$ pure $\mathrm{N}_{2}$ gas. Genomic DNA was extracted from individual colonies according to the protocol described for the Wizard Genomic DNA purification kit (Promega). Individual species were identified by $16 \mathrm{~S}$ rRNA fingerprinting using the method published earlier (Ngwenya, 2011).

\section{SRB cell surface characterisation}

Cells for cell surface characterisation experiments were harvested at Day 5 from cultures grown in Postgate medium (Medium B). Acid/base properties of SRB cells with regard to $\mathrm{H}^{+}$and $\mathrm{OH}^{-}$ion binding were studied by potentiometric titrations of solutions containing the harvested cells. Titrations were performed using an automated titration system comprising of a burette system, glass electrode and a $\mathrm{pH}$ meter (Metrohm 718 STAT-Titrino model, Metrohm, UK). Prior to titration, $0.3 \mathrm{~g}$ (wet weight) SRB cells were suspended in $25 \mathrm{ml}$ of the electrolyte solution which had been purged with $99.9 \%$ pure $\mathrm{N}_{2}$ for $60 \mathrm{~min}$ to eliminate $\mathrm{CO}_{2}$. The suspension was immediately placed into a sealed titration vessel with continuous stirring at $140 \mathrm{r} \cdot \mathrm{min}^{-1}$ under $\mathrm{N}_{2}$. Titrations were carried out by the gradual addition of pre-set small volumes of 0.1 $\mathrm{M} \mathrm{NaOH}$ or $0.1 \mathrm{M} \mathrm{HCl}$ titrant (standardized against reagent grade $\mathrm{KC}_{8} \mathrm{H}_{4} \mathrm{O}_{4} \mathrm{H}$ and $\mathrm{Na}_{2} \mathrm{CO}_{3}$, respectively). The titrator was set to add successive base or acid after a stability of $0.1 \mathrm{mV} \cdot \mathrm{s}^{-1}$ was attained. Three sets of duplicate SRB suspensions were first titrated with $0.1 \mathrm{M} \mathrm{HCl}$ to $\mathrm{pH} 4$ and then titrated to high $\mathrm{pH}$ $(\approx \mathrm{pH} 10)$ with $0.1 \mathrm{M} \mathrm{NaOH}$. Blank titrations devoid of SRB cells were also performed which served as controls. Reversibility of the SRB acid/base behaviour was established by performing reverse titrations. 


\section{$\mathrm{Sr}^{2+}, \mathrm{Co}^{2+}$ and $\mathrm{Cs}^{+}$adsorption experiments}

$\mathrm{Sr}^{2+}, \mathrm{Co}^{2+}$ and $\mathrm{Cs}^{+}$adsorption experiments were conducted under anaerobic conditions in batches with different $\mathrm{pH}$, ionic strength, and temperature conditions. Uptake of each metal was evaluated in a bacterial suspension consisting of approximately $1 \mathrm{~g}$ dry weight in basal mineral medium (BMM). The bacterial suspension in BMM was supplemented with the experimental metal at $100 \mathrm{mg} \times \ell^{-1}$ prepared in $0.1 \mathrm{M} \mathrm{NaNO}_{3}$. The initial values of $\mathrm{Sr}^{2+}$, $\mathrm{Co}^{2+}$ and $\mathrm{Cs}^{+}$concentration were prepared from high precision weight measurements using a Sartorius Cubis MSA524S100DI Analytical Balance (precision of $0.0001 \mathrm{~g}$ ). The measured values were compared with optimised values derived from simulation of the whole dataset using the programme MINTEQA2 (Allison et al., 1991). The initial values presented in Tables are nominal values from the weighed salts and prepared solutions from the measured values. After recording the initial $\mathrm{pH}$, the suspension was divided into a series of 100 -m $\mathrm{m}$ serum bottles, and the $\mathrm{pH}$ in each bottle was adjusted to the desired value by adding tear drops of concentrated $\mathrm{HNO}_{3}$ or $\mathrm{NaOH}$ solution. The serum bottles were immediately sealed with airtight rubber stoppers, and incubated in a Labcon SPL-MP 15 Orbital Shaker (Labcon Laboratory Services, South Africa) at $100 \mathrm{r} \cdot \mathrm{min}^{-1}$, and allowed to equilibrate for $3 \mathrm{~h}$ at $25 \pm 0.5^{\circ} \mathrm{C}$. At the end of the equilibration period, samples were collected by sterile needle and syringe followed by centrifugation to remove suspended solids and precipitates. The clear supernatant was then acidified to $1 \% \mathrm{v} / \mathrm{v} \mathrm{HNO}_{3}$ and stored at $4^{\circ} \mathrm{C}$, after which metals were analysed by atomic absorption spectrometry (AAS). Concentration of adsorbed metals on the biomass was calculated from desorption solutions after soaking the cells in mild acid concentration $(0.1 \mathrm{~N} \mathrm{HCl})$ for $5 \mathrm{~h}$ under continuous shaking. All experiments were performed in triplicate.

\section{Metal analysis}

Strontium concentration in liquid samples was determined using the AAnalyst 400 Perkin Elmer AAS (Perkin Elmer, Shelton, USA) at a wavelength of $460.7 \mathrm{~nm}$ in a nitrous oxideacetylene flame. Strontium ionization in the flame was suppressed by the addition of a potassium chloride solution to give a final concentration of $2 \mathrm{mg} \times \ell^{-1} \mathrm{~K}^{+}$in all samples including the standards and blank. Cobalt and caesium were measured similarly at wavelengths of 240.7 and $852.1 \mathrm{~nm}$, respectively.

\section{Surface complexation modelling approach}

Several researchers have applied different acid-base surface complexation models (SCM) to predict the identities of functional groups involved in the adsorption on the bacterial cell surface (Fein et al., 2005; Ngwenya et al., 2003; Tourney et al., 2008). In this study, the programme FITMOD, which is a modified version of the computer program FITEQL 2.0 by Westall (1982), was used to construct geochemical models describing proton interaction with the bacteria. A proton balance approach was utilized to optimize protonation constants of the various functional groups on the bacterial surface. The goodness-of-fit of the different models to the titration data was determined by the overall variance, $\mathrm{V}(Y)$, which is calculated by FITMOD as follows:

$$
V(Y)=\frac{Y_{I I} P\left(\frac{Y}{S_{Y}}\right)^{2}}{n_{p} \cdot n_{I}-n_{u}}
$$

where: $\mathrm{V}(Y)=$ overall variance, $Y=$ error in the mass balance calculations, $S_{\mathrm{Y}}=$ default experimental error calculated by FITMOD, $n_{\mathrm{p}}=$ number of data points, $n_{\mathrm{II}}=$ number of chemical components for which total and free concentrations are known, $P=$ data point location (count), and $n_{\mathrm{u}}=$ number of adjustable parameters. In Eq. 2, the value of $Y$ is updated by $Y_{\mathrm{II}}$ to optimise $\mathrm{V}(Y)$. Values of $\mathrm{V}(Y)$ between 1 and 20 generally indicate an acceptable fit to the data (Daughney et al., 2004). FITMOD incorporates a number of models; ranging from non-electrostatic single layer models (NEMSLMs) to electrostatic double-layer models (EM-DLMs). For comparison purposes, the titration experimental data obtained in this study were analysed to determine which model best represents the complexation behaviour on SRB cell surfaces. The titration data were plotted in terms of the concentration of deprotonated sites per mass of SRB (mol. $\left.\mathrm{g}^{-1}\right)$ as shown in Eq. 3 .

$$
\left[\mathrm{H}^{+}\right]_{\text {added/released }}=\left(\mathrm{C}_{a}-\mathrm{C}_{b}-\left[\mathrm{H}^{+}\right]+\left[\mathrm{OH}^{-}\right]\right) / m_{b}
$$

where: $\mathrm{C}_{\mathrm{a}}, \mathrm{C}_{\mathrm{b}},\left[\mathrm{H}^{+}\right]$and $\left[\mathrm{OH}^{-}\right]$are the molar concentrations of acid, base, $\mathrm{H}^{+}$and $\mathrm{OH}^{-}$species, respectively, and $m_{\mathrm{b}}$ is the concentration of SRB cells $\left(\mathrm{mg} \times \ell^{-1}\right)$ in the suspension.

The mass law relationship, in conjunction with the mole balance expressions, was used to define the adsorptive process. A 1:1 metal/surface site stoichiometry was used for all model calculations, and equilibrium constants for aqueous metal hydrolysis were obtained from simulated profiles following the method established by Baes and Mesmer (1976). This information was used to account for Sr, Co and Cs adsorption onto SRB cell surfaces according to Eq. 4 .

$$
M^{+}+R-A^{-} \leftrightarrow R-A M
$$

where: $\mathrm{M}^{+}=$target metal, $\mathrm{R}-\mathrm{A}^{-}=$deprotonated bacterial surface site, and $\mathrm{R}-\mathrm{AM}=$ metal-site complex.

Under equilibrium conditions partitioning between the solid surface and the aqueous phase is therefore quantified by the following mass law:

$$
K_{\mathrm{as}^{*}}=\frac{[R-A M]}{\left[M^{+}\right] \times\left[R-A^{-}\right]}
$$

where: $K_{\mathrm{as}^{*}}=$ stability constant based on the anionic property of the microbial cell wall, and square brackets denote concentrations of the specified species.

\section{EXPERIMENTAL RESULTS}

\section{Culture composition and sulphate-reducing activity}

The microbial species in the environmental mixed cultures were isolated and characterised to allow further development of more efficient pure cultures in future. The culture was maintained under sulphate-reducing conditions using a sulphate-reducing selective medium described earlier in this article. Individual species grown under the prescribed conditions confirmed the presence of sulphate-reducing organisms, both in stock and enrichment cultures. DNA was extracted and amplified from single colonies for use in the $16 \mathrm{~S}$ rRNA fingerprinting. For the Gram(+ve) colonies, 1000 replicates Boot-trap analysis was conducted to assess the reliability of the groupings with Paenibacillus polymyxa X60632 as an outgroup. Gram(+ve) species in samples after 2-day exposure to 75 $\mathrm{mg} \times \ell^{-1}$ of $\mathrm{Sr}^{2+}, \mathrm{Co}^{2+}$, and $\mathrm{Cs}^{+}$were identified as $98 \%$ homologs of Lysinicibacillus boronitolerans AB599591 (Fig. 1). These 


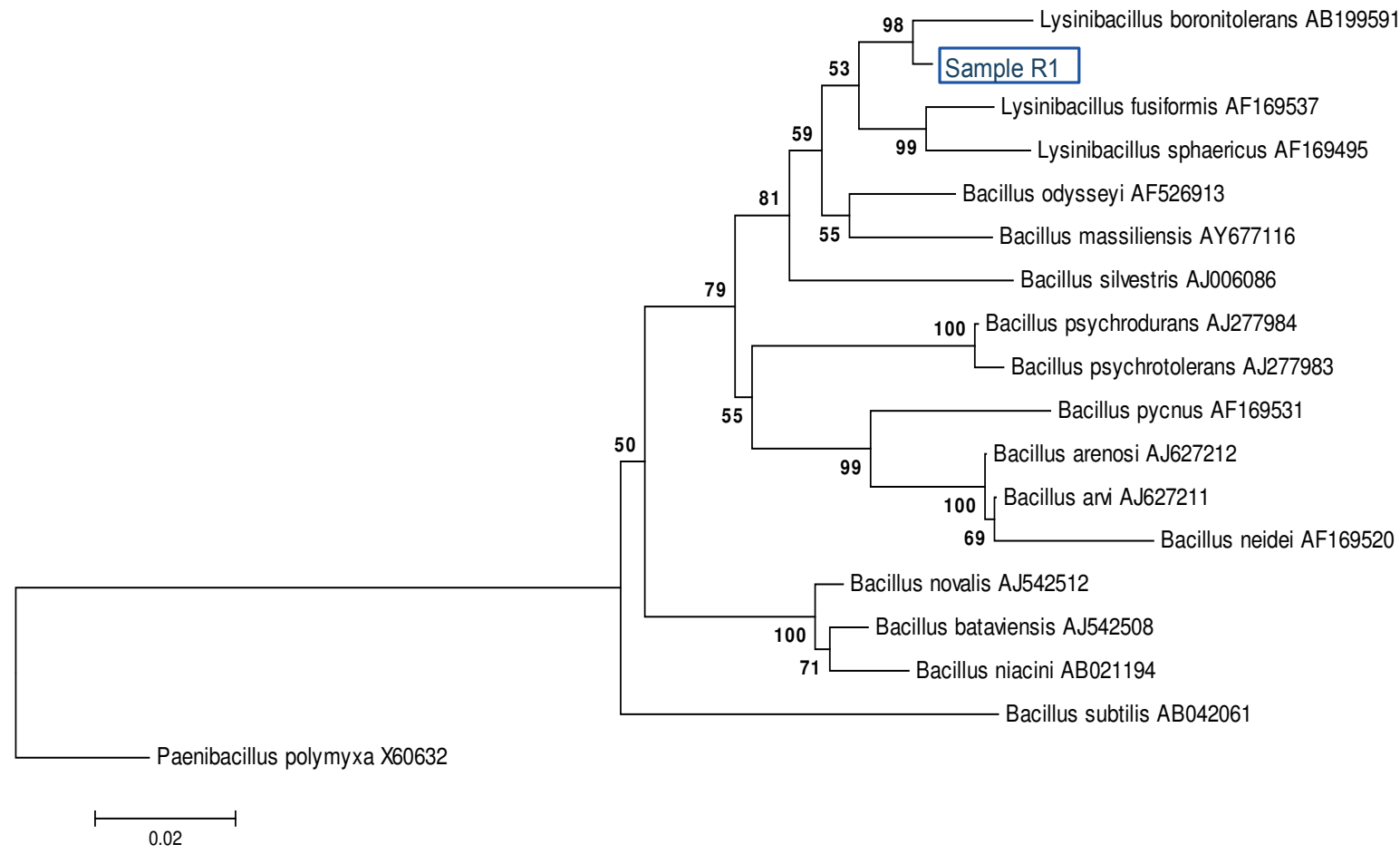

Figure 1

A phylogenetic tree diagram showing the identity of the Gram(+ve) colony type R1 association with Lysinibacillus boronitolerans AB199591

organisms characteristically possess a thick peptidoglycan cell wall rich in the carboxylic $(-\mathrm{COOH})$, sulphide $(-\mathrm{SH})$ and amine $\left(-\mathrm{NH}_{2}\right)$ functional groups from the amino acids components and hydroxyl $(-\mathrm{OH})$ groups from the glycan (sugar) units (Misra et al., 2014). The group also contained the sulphatereducing species Lysinibacillus sphaericus AF169495. Sulphatereducing activity of Lysinibacillus sphaericus was detected in earlier studies on acid mine drainage by Ahmed et al. (2007).

For Gram(-ve) colonies, Escherichia coli ATCC 11775 was used as the outer reference group. More diversity was observed among the Gram(-ve) species, with the three predominant colony types identified as $98-100 \%$ homologs of the sulphate-reducing subgroups containing Desulfomonile tiedgei AF418162, Desulfobacterium anilini AF418162 and Syntrophobacter wolinii X70905 (Fig. 2). Notably, the culture also contained a colony loosely associated with the species that are able to reduce sulphate under thermophilic conditions, i.e., Desulfacinum infernum L27426 and Desulfacinum hydrothermale AF170417. Unlike Gram(+ve) cells, Gram(-ve) cells do have a thick layer of peptidoglycan. Instead, Gram(-ve) cells tend to produce a large amount of exopolysaccharide fibres and transmembrane proteins that could serve as binding sites for metals. Adsorption on Gram(-ve) cells is therefore expected to involve more structures than in Gram(+ve) cells.

The metabolic activity of the microorganisms during the log-growth phase explained the sulphate-reducing activity in the cultures. This was demonstrated by the disappearance of $\mathrm{SO}_{4}{ }^{2-}$ and the accumulation of total sulphide (HS- and $\mathrm{S}^{2-}$ ) in the system. An example of the performance of the culture in reducing sulphate is illustrated in Fig. 3a. The results show reduction of $\mathrm{SO}_{4}^{2-}$ in solutions from $3.02 \mathrm{~g} \times \ell^{-1}$ to $1.40 \mathrm{~g} \times \ell^{-1}$, a reduction of $53.4 \%$, in 14.6 days with concomitant accumulation of HS-, from 0.04 to $0.58 \mathrm{~g} \times \mathrm{\ell}^{-1}$, a difference of $93.1 \%$ in the same time period (Fig. 3a, b). Additionally, $\mathrm{SO}_{4}^{2-}$ removal in the system correlated with cell production (Fig. 3c). It appears therefore that sulphate reduction was necessary for cell growth in the mixed culture used in this study.

\section{Partitioning of reactive species on cell surface}

Scanning electron micrographs of SRB biomass in a $75 \mathrm{mg} \times \ell^{-1}$ $\mathrm{Sr}^{2+}$ solution showed white precipitates deposited in the vicinity of cells (c). Figure 4A shows that precipitates were absent in a heat-killed culture control suggesting that metal ion precipitation may require some metabolic factors to occur. The energy dispersion x-ray (EDX) analysis showed that Sr was not a dominant species on the surface of cells with only $0.5 \%$ detected on the surface. Speciation analysis of bacteria-free controls revealed that the solutions were undersaturated with respect to insoluble $\mathrm{Sr}$ species. This is consistent with the observation of adsorption as the dominant mechanism for metal removal from solution. The results show significant $\mathrm{Sr}^{2+}$ adsorbed to the cells (Fig. 4B). EDX analysis of the cells from the live cultures showed that $\mathrm{Sr}^{2+}$ comprised about $68 \%$ of the elemental composition at the cell surfaces. Thus strontium was the dominant species on the surface of live cultures which indicates active adsorption of strontium on live culture cells.

A mass balance analysis was conducted to determine the distribution of cell surface functional groups on SRB cells as shown in Fig. 5a, b. The analysis was conducted from solutions containing $75 \mathrm{mg} \times \ell^{-1}$ of $\mathrm{Sr}^{2+}, \mathrm{Co}^{2+}$ and $\mathrm{Cs}^{+}$, i.e., $75 \mathrm{mg} \times \ell^{-1}$ of each species. The mass balance on the adsorbed and desorbed species shows that most of the metallic species were localised on the surface of the cells. The desorption analysis showed that up to $70 \%$ of $\mathrm{Sr}^{2+}, 43 \%$ of $\mathrm{Co}^{2+}$ and $55 \%$ of $\mathrm{Cs}^{+}$adsorbed on live cells $\left(44 \% \mathrm{Sr}^{2+}, 50 \% \mathrm{Co}^{2+}\right.$ and $65 \% \mathrm{Cs}^{+}$adsorbed on heat-killed cells) was exchangeable. This suggests that the majority of adsorbed species were bound to the cells by weak electrostatic 


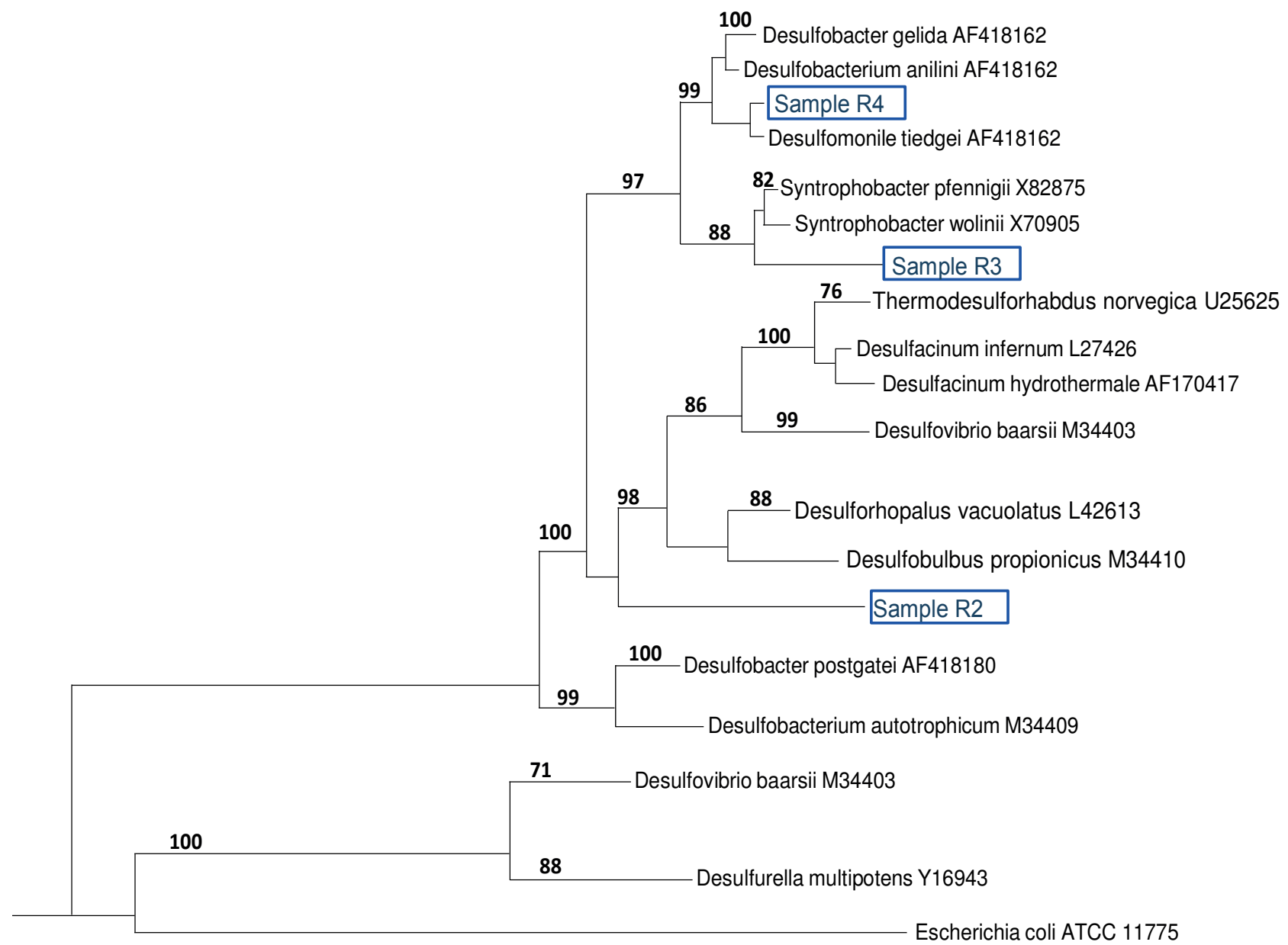

Figure 2

A phylogenetic tree diagram showing the identity of the Gram-positive colony types $R 2, R 3$ and $R 4$ identified as homologs of Desulfomonile tiedgei AF418162 (Sample R4), Syntrophobacter wolinii X70905 (Sample R3), and Desulforhopalus vacuolatus L42613 (Sample R2)

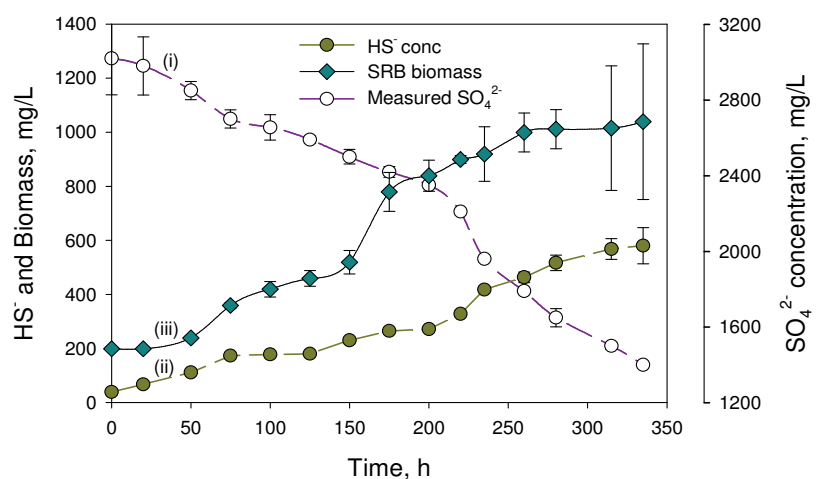

Figure 3

Concentration observations in a batch study showing (i) $\mathrm{SO}_{4}{ }^{2-}$ reduction, (ii) HS accumulation, and (iii) viable biomass growth with time. A 53.6\% reduction of sulphate is observed concurrent with $93.1 \%$ accumulation of HS and a corresponding increase in biomass concentration (sample size $n=3$, error bar $=$ sample standard deviation) interactions that were easily disrupted by a change in the ionic orientation of the medium solution such as an increase in $\mathrm{H}^{+}$. The proportions of fission products $\mathrm{Sr}^{2+}$ and $\mathrm{Cs}^{+}$covalently bonded to the cell surfaces were found to be distributed on carboxylates (18-28\%), oxides (8-10\%), and sulphides (3-5\%). The residue contained less the $0.3 \%$ of $\mathrm{Sr}^{2+}$ and $\mathrm{Cs}^{+}$. The distribution of $\mathrm{Co}^{2+}$ was significantly different as shown by the grey bars in the graph (Fig. 5a, b). Almost $50 \%$ of cobalt was detected in the precipitate residue. Further analysis was conducted on the cell surface characteristics using potentiometric titration to determine the predominant adsorption process. The information was used later in deciding the choice of complexation model during equilibrium modelling using FITMOD.

\section{Distribution of cell surface functional groups}

Since up to $70 \%$ of the metals in solution were exchangeable using a dilute acid regeneration process, a non-electrostatic model (NEM) was attempted first. Analysis of the potentiometric titration data yielded 4 buffering equilibrium points on the cell surface, i.e. - Point $1\left(p K_{a}=4-5\right)$ associated with $-\mathrm{COOH}$ 

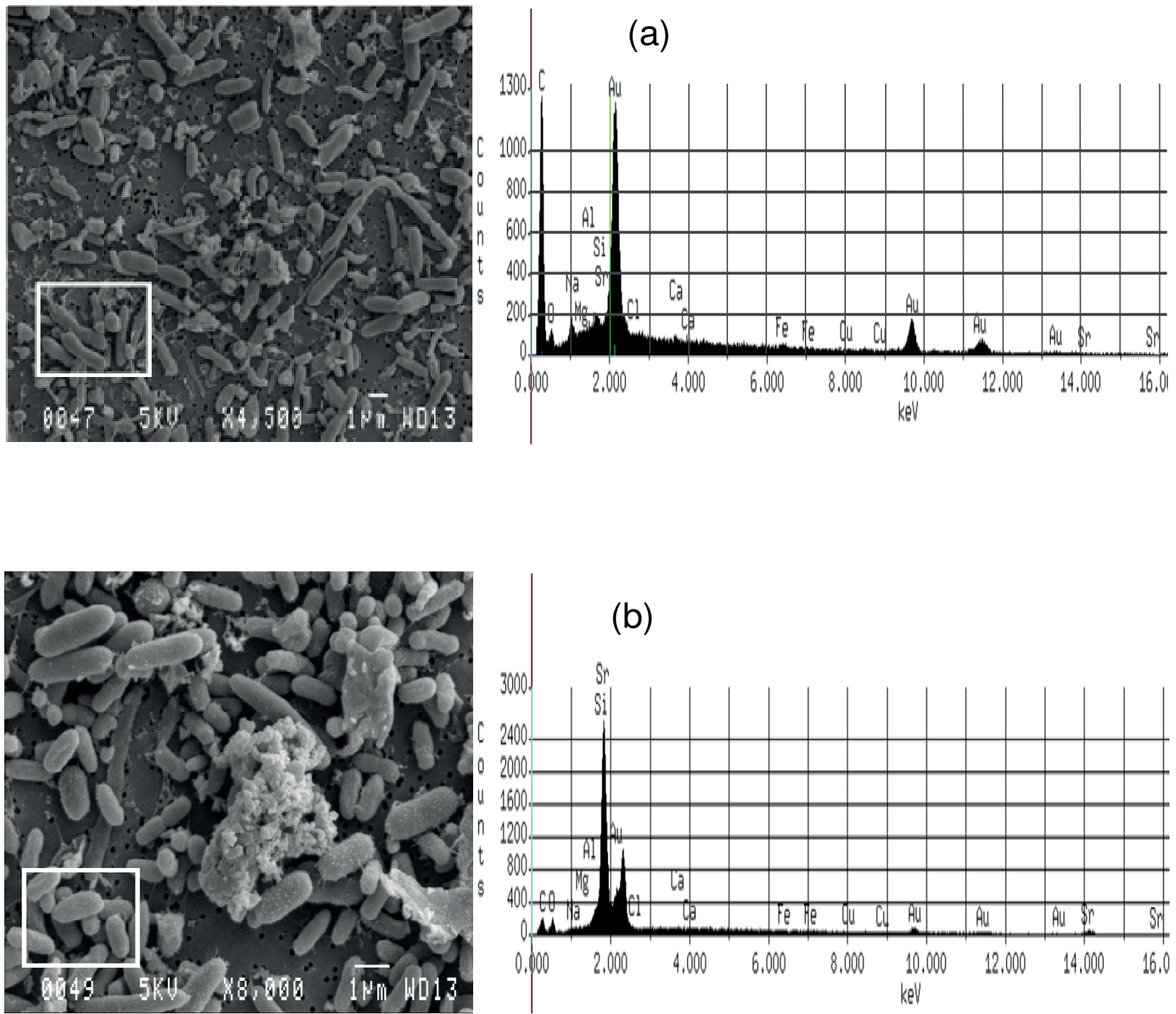

Figure 4

SEM image and EDX analysis of live culture exposed to $75 \mathrm{mg} \times \ell^{-1} \mathrm{Sr}^{2+}$ - elemental analysis on cell surface from $(A) 0.2 \% \mathrm{Sr}$ detected on the surface of cells heat-killed culture (Control) and (B) $68.22 \%$ detected on the surface of live cells. The white box indicates area scanned with EDX. (From: Ngwenya and Chirwa, 2011)
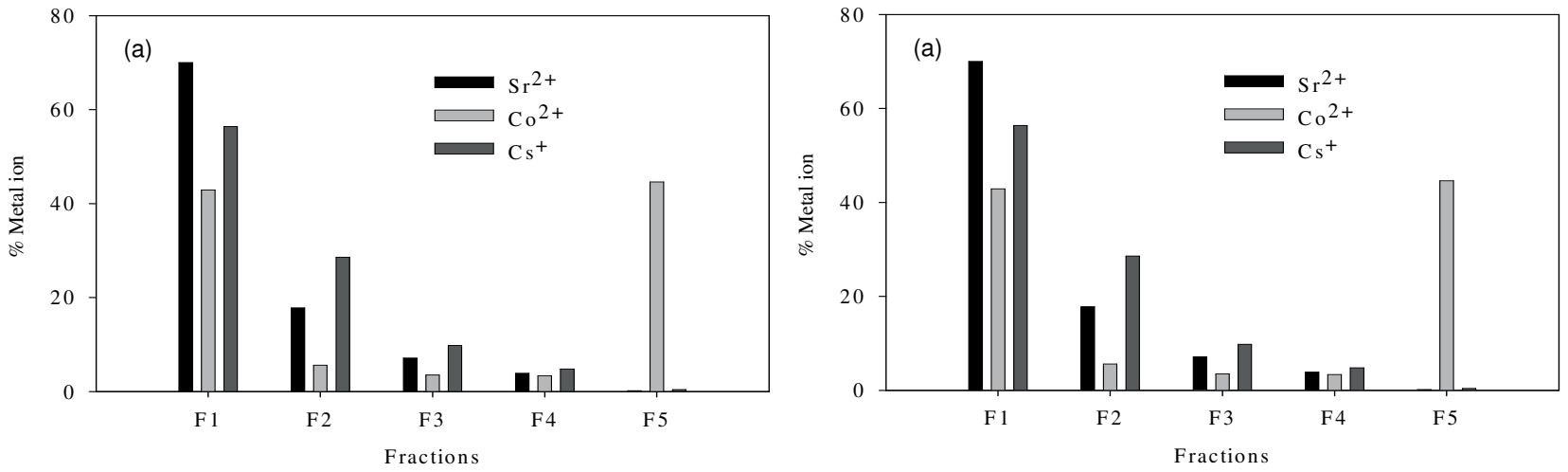

Figure 5

Partitioning of $\mathrm{Sr}^{2+}, \mathrm{CO}^{2+}$ and $\mathrm{Cs}^{+}$species on available (A) and dead (B) SRB biomass. $\mathrm{F} 1=$ exchangeable, $F 2=$ carboxylates, $F 3=$ oxides, $F 4=$ sulphide/ organics, and F5 = residential fraction 
Table 1

Compilation of SRB deprotonation constants, surface site densities and variance at $0.01 \mathrm{M}, 0.10 \mathrm{M}$ and $0.50 \mathrm{M} \mathrm{NaNO}_{3}$ and $25^{\circ} \mathrm{C}$ as calculated by FITMOD

\begin{tabular}{|c|c|c|c|c|c|c|c|c|c|}
\hline \multirow{2}{*}{$\begin{array}{l}\text { lonic } \\
\text { strength }\end{array}$} & \multicolumn{4}{|c|}{$p K_{a}$ values $^{\mathrm{a}}$} & \multicolumn{4}{|c|}{ Site concentrations $\left(\times 10^{-3} \mathrm{~mol} \times \ell^{-1}\right)$} & \multirow[t]{2}{*}{$\mathrm{V}(Y)^{\mathrm{b}}$} \\
\hline & 1 & 2 & 3 & 4 & $\mathrm{C}_{1}$ & $\mathrm{C}_{2}$ & $C_{3}$ & $\mathrm{C}_{4}$ & \\
\hline $0.01 \mathrm{M}$ & $\begin{array}{l}4.94 \\
4.46 \\
4.34 \\
4.31\end{array}$ & $\begin{array}{l}7.22 \\
6.51 \\
6.30\end{array}$ & $\begin{array}{l}9.55 \\
8.13\end{array}$ & 10.18 & $\begin{array}{l}3.739 \\
2.362 \\
2.041 \\
1.966\end{array}$ & $\begin{array}{l}2.985 \\
2.187 \\
1.893\end{array}$ & $\begin{array}{l}2.759 \\
1.002\end{array}$ & 3.473 & $\begin{array}{c}585.8 \\
73.0 \\
4.06 \\
1.17\end{array}$ \\
\hline $0.1 \mathrm{M}$ & $\begin{array}{l}5.00 \\
4.48 \\
4.35 \\
4.32\end{array}$ & $\begin{array}{l}7.35 \\
6.61 \\
6.38\end{array}$ & $\begin{array}{l}9.53 \\
8.05\end{array}$ & 10.1 & $\begin{array}{l}4.597 \\
2.844 \\
2.451 \\
2.362\end{array}$ & $\begin{array}{l}3.415 \\
2.525 \\
2.124\end{array}$ & $\begin{array}{l}2.982 \\
1.104\end{array}$ & 3.576 & $\begin{array}{c}601.3 \\
85.4 \\
14.7 \\
12.2\end{array}$ \\
\hline $0.5 \mathrm{M}$ & $\begin{array}{l}4.91 \\
4.56 \\
4.37 \\
4.34\end{array}$ & $\begin{array}{l}7.90 \\
6.41 \\
6.15\end{array}$ & $\begin{array}{l}9.41 \\
8.07\end{array}$ & 9.96 & $\begin{array}{l}4.345 \\
2.928 \\
2.305 \\
2.201\end{array}$ & $\begin{array}{l}3.970 \\
2.404 \\
2.016\end{array}$ & $\begin{array}{l}3.653 \\
1.362\end{array}$ & 3.964 & $\begin{array}{c}543.7 \\
71.2 \\
4.51 \\
1.77\end{array}$ \\
\hline
\end{tabular}

${ }^{a} p K$ values corrected for ionic strength and temperature effects ${ }^{\mathrm{b}}$ Overall variance computed by FITMOD

functional groups, Point $2\left(p K_{\mathrm{a}}=6-7\right)$ associated with $-\mathrm{H}_{2} \mathrm{PO}_{4}$ functional groups, Point $3\left(p K_{\mathrm{a}}=8-9\right)$ associated with ammonium groups, and Equilibrium Point $4\left(p K_{\mathrm{a}}=10\right)$ being the protonated amine groups (Table 1). Some of the anticipated functional groups such as hydroxyl-OH groups $\left(p K_{\mathrm{a}}=17\right)$ and amide $\left(p K_{a}=15\right)$ lie outside the scanned range.

It was observed in all of the tested cases that the ammonium $-\mathrm{NH}_{4}^{+}\left(p K_{\mathrm{a}}=9\right)$ and protonated amine $-\mathrm{NH}_{2} \cdot \mathrm{H}^{+}\left(p K_{\mathrm{a}}=\right.$ 10) comprised the majority of reactive sites (Table 1). However, the majority of the values in the preferred operational range for the culture $\mathrm{pH} 4.5-6.8$ were a combination of the carboxylic $(-\mathrm{COOH})$ groups with approximately $40 \%$ of the reaction sites identified in this region. The distribution of the reactive sites, with more reactive sites in the lower $p K_{\mathrm{a}}$ ranges, shows that the Gram(+ve) species in the culture played a greater role in the adsorption of the metals.

The density of reactive sites in the culture ranged from $10.2 \times 10^{-3}$ to $12.2 \times 10^{-3} \mathrm{~mol} \times \ell^{-1}$ which is much higher than values previously observed with Gram(-ve) pure culture from literature. Previous studies on other selected bacteria, as described by other models, yielded lower total site concentrations of reactive sites (in decreasing order); $3.33 \times 10^{-3} \mathrm{~mol} \times \mathrm{\ell}^{-1}$ for Pseudomonas aeruginosa, $2.24 \times 10^{-3} \mathrm{~mol} \times \ell^{-1}$ for Escherichia coli, $1.42 \times 10^{-3}$ mol $\times \ell^{-1}$ for Aquabacterium commune, $1.46 \times 10^{-3}$ mol $\times \ell$ ${ }^{-1}$ for Calothrix sp., $1.27 \times 10^{-3} \mathrm{~mol} \times \mathrm{\ell}^{-1}$ for Enterobacteriaceae sp., and $7.8 \times 10^{-3} \mathrm{~mol} \times \ell^{-1}$ for Shewanella putrefaciens (Joo et al., 2010; Almaguer-Cantú, 2011; Haas et al., 2001). The higher values in the present culture are attributed to the higher exposure to $-\mathrm{COOH}$ and $-\mathrm{OH}$ group and other protonated amine groups in the cell wall of the Gram(+ve) component of the culture.

\section{Effect of ionic strength on equilibrium states}

The dependence of uptake rate of the test compounds on ionic strength was used to determine whether metal adsorption occurs as an inner-sphere or outer-sphere complex. In particular, outersphere complexes are intrinsically more sensitive to variation in ionic strength than inner-sphere complexes, as the availability of free sorbent binding sites tends to decrease with increasing electrolyte concentration (Jonáš and Nordén, 1974). In the outersphere complexes, uptake of ionic species is mediated by the bipolar hydronium ions that form the interface layer between the charged surface (sorbent) and candidate ionic species in solution. Increasing ionic strength in the solution reduces the accessibility of sites to ionic species in solution due to the changing polarity of the surface layer (Donath et al., 1997).

In this study, the ionic strength of the solution significantly affected the uptake of the fission products (Fig. 6). For example, the uptake of $\mathrm{Sr}^{2+}$ decreased by $10 \%$ after increasing ionic strength from 0.1 to $0.5 \mathrm{M}$ (Fig. 6a). Similar results were obtained in the cases of $\mathrm{Co}^{2+}$ and $\mathrm{Cs}^{+}$, where the adsorption of $\mathrm{Co}^{2+}$ and $\mathrm{Cs}^{+}$onto the SRB biomass decreased with increasing ionic strength (Fig. 6b, c).

The decreased uptake of $\mathrm{Cs}^{+}$ions by biosorbents in the presence of excess monovalent (electrolyte) cations has been reported before (Harjula and Lehto, 1986; Solecki, 2006). This phenomenon has been attributed to a number of factors, including competition for deprotonated binding sites between the metal ions and the background electrolyte cation $\left(\mathrm{Na}^{+}\right)$ (Solecki, 2006), and changes in the activity of both the metal binding functional group sites and aqueous metal ions as a function of ionic strength (Borrok and Fein, 2005).

\section{Effect of pH on equilibrium states}

Solution $\mathrm{pH}$ affected the surface charge of the adsorbent by varying the degree of ionization and speciation of the adsorbate. The results from batch experiments conducted under varying $\mathrm{pH}$ and constant initial concentration showed an increase in the uptake of divalent species, $\mathrm{Sr}^{2+}$ and $\mathrm{Co}^{2+}$ due to increased $\mathrm{pH}$, whereby the uptake of the monovalent species $\mathrm{Cs}^{+}$was inhibited at high $\mathrm{pH}$. At an initial concentration of $75 \mathrm{mg} \times \mathrm{\ell}^{-1}$ and $\mathrm{pH}$ range 2-9, results obtained showed that most of the $\mathrm{Sr}(99.8 \%)$ and Cs (99.96\%) species in solution were present in their highly dissociated forms $\left(\mathrm{Sr}^{2+}\right.$ and $\mathrm{Cs}^{+}$, respectively). Only about $0.2 \%$ and $0.04 \%$ existed as $\mathrm{SrCl}^{+}$and $\mathrm{CsCl}$, respectively. This observation suggests that $\mathrm{Sr}$ and Cs cations undergo limited hydrolysis, which is in agreement with earlier findings by Baes and Mesmer (1976). In the case of cobalt, both initial concentration and $\mathrm{pH}$ played a significant role in its speciation. Generally, an increase in $\mathrm{pH}$ resulted in a decrease in the highly dissociated Co species. At low pH (pH 2-4), 99.7\% Co species were present as $\mathrm{Co}^{2+}$ and $0.3 \%$ as $\mathrm{CoNO}_{3}^{+}$(Fig. 7). At near-neutral pH (pH 5-7), slight precipitation occurred as Co species were distributed as follows: 

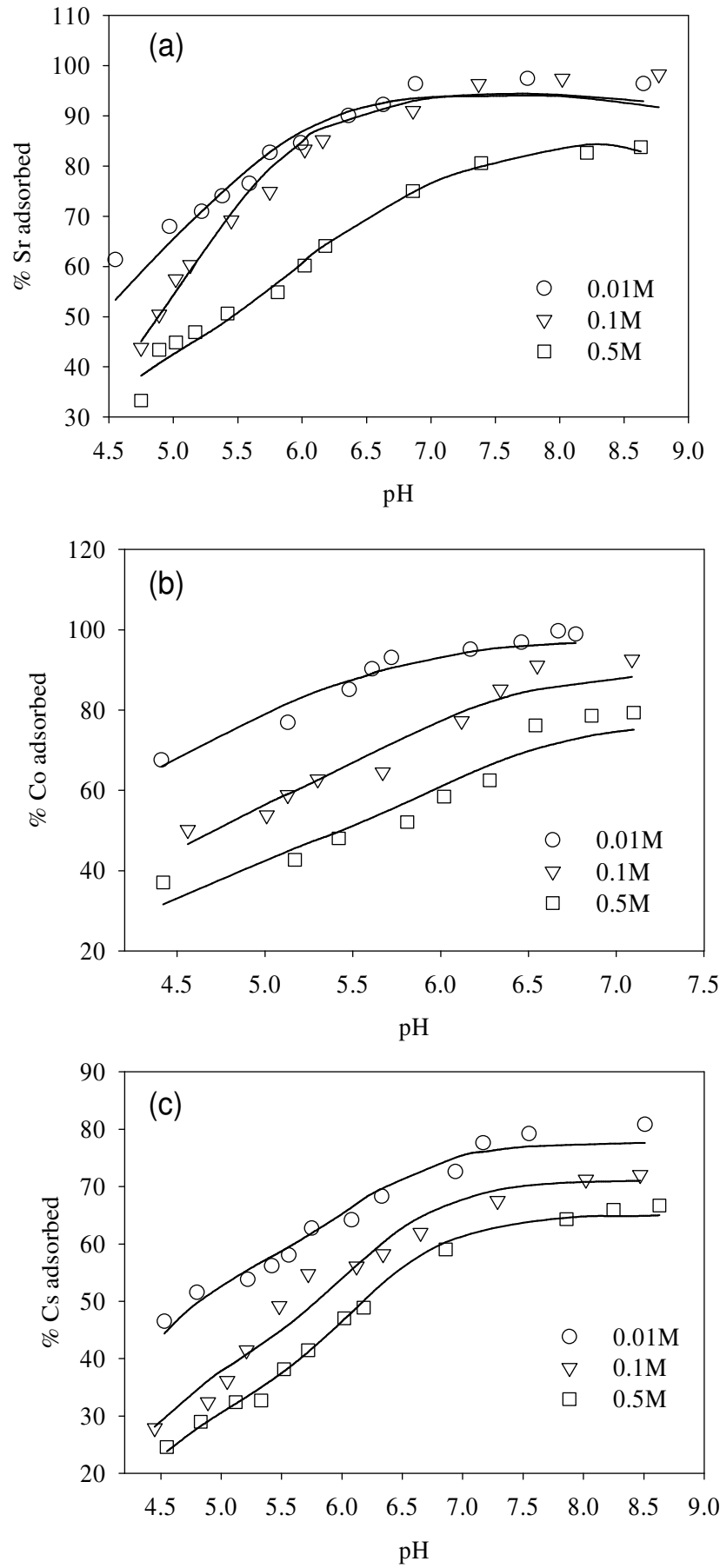

Figure 6

lonic strength dependence on the adsorption behaviour of the different metals (a) $\mathrm{Sr}^{2+}$, (b) $\mathrm{CO}^{2+}$ and (c) $\mathrm{Cs}^{+}$, onto a viable SRB consortium at $25^{\circ} \mathrm{C}$.

Experimental conditions were: initial concentration: $2.85 \times 10^{-4} \mathrm{M}$, $8.85 \times 10^{-5} \mathrm{M}$ and $3.76 \times 10^{-5} \mathrm{M}$, of $\mathrm{Sr}^{2+}, \mathrm{CO}^{2+}$ and $\mathrm{CS}^{+}$, respectively, and bacterial biomass $=2.16( \pm 0.03) \mathrm{g}$ cells (wet weight) $\times \ell^{-1}$ in each experimental batch

99.68\% $\mathrm{Co}^{2+}, 0.3 \% \mathrm{CoNO}_{3}{ }^{+}$and $0.016 \% \mathrm{CoOH}^{+}$. Increasing the $\mathrm{pH}$ to 8 resulted in $\mathrm{Co}^{2+}$ precipitation due to the formation of $\mathrm{Co}(\mathrm{OH})_{2}(0.12 \%)$, with a resultant distribution of Co species as follows: $\sim 97 \% \mathrm{Co}^{2+}$ and $2 \% \mathrm{CoOH}^{+}$. Further increase in $\mathrm{pH}$ to 9 resulted in increased precipitation with approximately $10 \%$ of the initial concentration present as $77 \% \mathrm{Co}^{2+}, 0.3 \%$ as $\mathrm{CoNO}_{3}^{+}, 13 \%$ $\mathrm{CoOH}^{+}$, and $0.1 \% \mathrm{Co}_{4}(\mathrm{OH})_{4}^{4+}$.
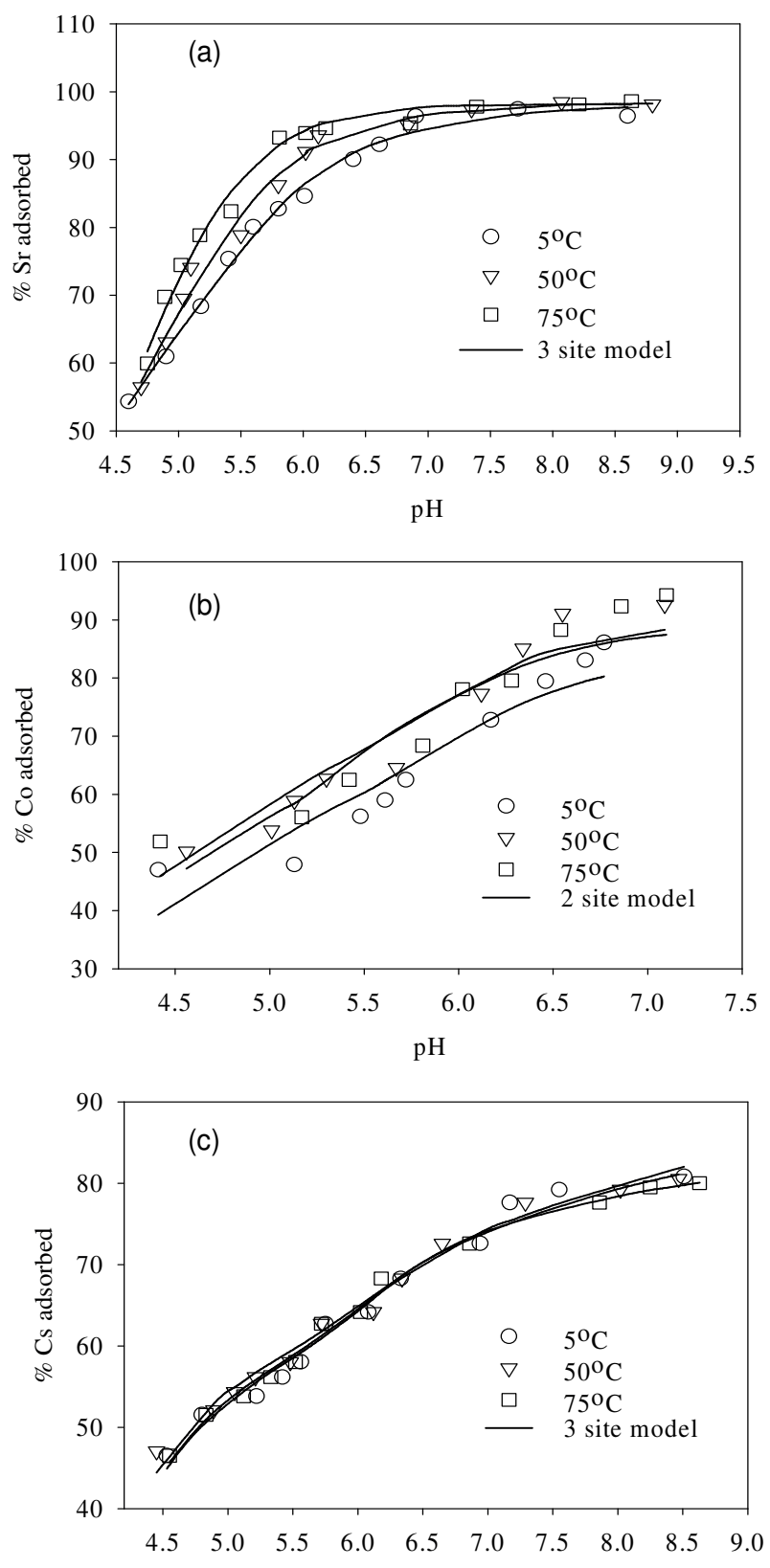

Figure 7

Dependence of metal uptake on temperature tested at $5^{\circ} \mathrm{C}, 50^{\circ} \mathrm{C}$, and $75^{\circ} \mathrm{C}$, with (a) $\mathrm{Sr}^{2+}$ showing a 3-site model, (b) $\mathrm{Co}^{2+}$ showing a 2-site model, and (c) $\mathrm{Cs}^{+}$showing a 3-site model, after fitting the data against the NEM model in FITMOD

As mentioned above, $\mathrm{Cs}^{+}$and $\mathrm{Co}^{2+}$ were affected by the solution $\mathrm{pH}$ in opposite ways. Whereas $\mathrm{pH}$ increase enhanced $\mathrm{Co}^{2+}$ removal, high $\mathrm{pH}$ inhibited $\mathrm{Cs}^{+}$removal. The dependence of $\mathrm{Cs}^{+}$ on $\mathrm{pH}$ indicates association with the lower $p K_{\mathrm{a}}$ reaction sites such as the carboxylic groups $\left(p K_{\mathrm{a}}=4.5\right)$. In the low $p K_{\mathrm{a}}$ groups, the reaction sites are increasingly deprotonated as $\mathrm{pH}$ values exceed 6 . The deprotonation of carboxylic groups generates a net negative charge at the surface, which favours the binding of monovalent cationic species but these sites will trigger competition with other monovalent ions from the solution such as $\mathrm{Na}^{+}$and $\mathrm{K}^{+}$from the growth medium (Solecki, 2006; Apell and Diller, 2002). 
Table 2

Compilation of $\mathrm{Sr}^{2+}, \mathrm{Co}^{2+}$ and $\mathrm{Cs}^{+}$stability constants and variance at different temperatures and $0.1 \mathrm{M}$ and $25^{\circ} \mathrm{C}$ as calculated by FITMOD using the non-electrostatic model

\begin{tabular}{|c|c|c|c|c|c|}
\hline \multirow[t]{2}{*}{ Metal ion } & \multirow[t]{2}{*}{ Temperature $\left({ }^{\circ} \mathrm{C}\right)$} & \multicolumn{3}{|c|}{ Stability constants } & \multirow[t]{2}{*}{$\mathbf{V}(Y)^{\mathrm{a}}$} \\
\hline & & 1 & 2 & 3 & \\
\hline $\mathrm{Sr}^{2+}$ & $\begin{array}{c}5 \\
50 \\
75\end{array}$ & $\begin{array}{l}1.54 \\
1.69 \\
1.91 \\
\end{array}$ & $\begin{array}{l}2.48 \\
2.20 \\
2.07\end{array}$ & $\begin{array}{l}3.37 \\
3.34 \\
4.06\end{array}$ & $\begin{array}{l}0.65 \\
1.33 \\
1.09 \\
\end{array}$ \\
\hline $\mathrm{Co}^{2+}$ & $\begin{array}{c}5 \\
50 \\
75\end{array}$ & $\begin{array}{l}1.65 \\
1.61 \\
1.54\end{array}$ & $\begin{array}{l}3.07 \\
2.81 \\
2.86\end{array}$ & $\begin{array}{l}-- \\
-- \\
--\end{array}$ & $\begin{array}{l}5.89 \\
2.91 \\
5.31\end{array}$ \\
\hline $\mathrm{Cs}^{+}$ & $\begin{array}{c}5 \\
50 \\
75\end{array}$ & $\begin{array}{l}1.58 \\
1.56 \\
1.58\end{array}$ & $\begin{array}{l}3.44 \\
3.47 \\
3.43\end{array}$ & $\begin{array}{l}4.78 \\
4.85 \\
5.03\end{array}$ & $\begin{array}{l}0.19 \\
0.15 \\
0.08\end{array}$ \\
\hline
\end{tabular}

${ }^{a}$ Overall variance computed by FITMOD

Biochem. 39 (8) 909-916.

\section{Effect of temperature on equilibrium states}

The effect of temperature on the adsorption behaviour was evaluated within the physiologically relevant $\mathrm{pH}$ range $(\mathrm{pH}=4.5$ to 8.5 ) and a range of temperatures $\left(5,50\right.$ and $70^{\circ} \mathrm{C}$ ) (Table 2, Fig. 7). The $\mathrm{pH}$ range evaluated is related to the medium-range reaction sites containing the carboxylate, phosphate, and possibly some phenolic functional groups. The results show that, for $\mathrm{Sr}^{2+}$, the adsorption reaction responded to temperature at lower $\mathrm{pH}$ values ( $\mathrm{pH} £ 7.5$ ), whereas for monovalent species $\mathrm{Cs}^{+}$the adsorption reaction rate did not respond to the change in temperature (Table 2, Fig. 7a, c). For $\mathrm{Co}^{2+}$, the uptake rate was slightly higher at high temperatures (Fig. 7b). Compared with the results for the effect of ionic strength (Fig. 6), the effect of temperature is shown to be less significant than the effect of ionic strength. However, Fig. 7 further demonstrates that $\mathrm{pH}$ change increases the uptake rate with the influence extending from low $\mathrm{pH}$ to $\mathrm{pH}$ 7.5. At $\mathrm{pH}$ values above 7.5 , further increase in $\mathrm{pH}$ has no effect on the uptake rate for all three of the metal species tested in this study. This may be due to direct precipitation of metallic species by the electronegative anions in the solution.

\section{DISCUSSION}

A preliminary analysis was conducted to determine the adsorption capacity of SRB cells using the classical Langmuir and Freundlich isotherm models (Ngwenya and Chirwa, 2010). Since the equilibrium data showed a definite saturation characteristic, the Langmuir model was adapted for adsorption capacity. The observed binding capacities for binary and tertiary ion systems was $\mathrm{Sr}^{2+}>\mathrm{Co}^{2+}>\mathrm{Cs}^{+}$(with $q_{\max }=405.5,203.3$ and 192.2 $\mathrm{mg}$ ion $\cdot \mathrm{g} \mathrm{cells}^{-1}$, respectively) (Ngwenya, 2011). However, the aim of this stage of the study was to investigate the features associated with the binding capacities, such as concentration of reaction sites and distribution of functional groups on the cell surfaces. The classical isotherms could not be used to gain the above knowledge since they are based on highly theoretical concepts which do not reflect the actual nature of chemical reactions. An equilibrium modelling approach was therefore followed to evaluate the ion exchange properties, speciation of species, and dissociation factors, over a range of $\mathrm{pH}$, ionic strength and temperature conditions.

Results obtained from potentiometric titration studies of the bacterial consortium gave a qualitative measure of the acidbase properties of the bacterial cell surface. Results from this study indicate that the surfaces of the present SRB consortium can be adequately defined by a 4 -site non-electrostatic model as shown in Table 1 . Site 1 corresponds to carboxylic acid functional groups ( $p K_{\mathrm{a}}=4-5$ ). This reaction site was seen to be critical in the binding of monovalent ionic species such as $\mathrm{Cs}^{+}$. Carboxylic groups deprotonate easily as the $\mathrm{pH}$ of the solutions rises above 6 , thereby exposing reaction sites for the $\mathrm{Cs}^{+}$binding. The other two divalent species $\mathrm{Sr}^{2+}$ and $\mathrm{Co}^{2+}$ were heavily influenced by the near-neutral $\mathrm{pH}$ reaction sites $\left(p K_{\mathrm{a}}=6-7\right.$ and $p K_{\mathrm{a}}=8$ ). The result of this association was the direct opposite on the effect of $\mathrm{pH}$ on $\mathrm{Cs}^{+}$uptake. The implication on the binding of the metals to cell surfaces is significant since $\mathrm{pH}$ will play a critical role in determining the ionic strength of the solution.

The most abundant proton binding site on the SRB culture belonged to Site 4 (protonated amide groups), which accounted for about $39 \%$ of the total concentration of binding sites for the consortium. The $p K_{\mathrm{a}}$ of this site is very high - in the region of $p K_{\mathrm{a}} 10.0$, which means that binding to this site will be preferred at a relatively high $\mathrm{pH}$. However, the results from Fig. 5 suggest that overall uptake of the metals under higher $\mathrm{pH}$ and higher ionic strength actually decreased. This discrepancy is explained by high precipitation rates at the high $\mathrm{pH}$ and competition for sites with other ions in solution under high ionic strength. The sum of all the conditions and effects above leads us to conclude that the most critical sites of reaction in the actual operation range would be the carboxylic $p K_{\mathrm{a}}=5$ and phosphate $p K_{\mathrm{a}}$ range $6-8$. Over this $p K_{\mathrm{a}}$ range, an optimum amount of deprotonated reaction sites will be available and the ionic strength will be weak enough to avoid precipitation and covalent bonding under high ionic strength conditions. Operation of $\mathrm{pH}$ under the Site $2-3$ conditions ( $\mathrm{pH} \mathrm{6-7)}$ ) will provide conditions for weak electrostatic interactions necessary for optimising the exchangeable fraction (F1) in Fig. 5a.

Estimation of reaction site concentration is important in the evaluation of the quality of SRB cells as a potential biosorbent for actual application. Through this analysis, it is possible to compare the quality of the current culture with that previously reported for other biosorbents. The total concentration of reaction sites $\left(C_{\text {tot }}\right)$ increased slightly with increasing ionic strength. The observed values were $10.2 \times 10^{-3}, 11.3 \times 10^{-3}$ and $12.2 \times 10^{-3}$ mol $\times \ell^{-1}$ (average standard error, $\sigma_{\mathrm{av}}=0.15 \times 10^{-3}$ ) at ion concentrations of $0.01 \mathrm{M}, 0.1 \mathrm{M}$ and $0.5 \mathrm{M}$, respectively. The values observed here are 3 to 4 times higher than values obtained from pure cultures of Pseudomonas aeruginosa $\left(3.31 \times 10^{-3} \mathrm{~mol} \times \mathrm{\ell}^{-1}\right)$, Escherichia coli $\left(2.24 \times 10^{-3} \mathrm{~mol} \times \ell^{-1}\right)$, Aquabacterium commune 
$\left(1.42 \times 10^{-3} \mathrm{~mol} \times \ell^{-1}\right)$, Calothrix sp. $\left(1.46 \times 10^{-3} \mathrm{~mol} \times \ell^{-1}\right)$, and Enterobacteriaceae sp. $\left(1.27 \times 10^{-3} \mathrm{~mol} \times \ell^{-1}\right)$ (Almaguer-Cantú et al., 2011; Yee and Fein, 2001). The only species reported in the literature to yield values of the same order of magnitude as the culture from this study was Shewanella putrefaciens $\left(7.8 \times 10^{-3}\right.$ mol $\times \ell^{-1}$ ) (Haas et al., 2001). Therefore, the high buffering capacity and metal ion adsorption capacity demonstrated by the mixed SRB culture can be directly attributed to the high total concentration of reactive sites. The culture was characteristically different from the previously studied cultures due to the presence of the Gram(+ve) species with an increased number of polar function groups $(-\mathrm{COOH}$ and $-\mathrm{OH})$.

In summary, findings from this study strongly suggest that the biological adsorption and stability of the metal ions is influenced by surface properties of the consortium (including the concentration of the surface functional groups), and metal speciation in the aqueous phase. Both the ionic strength and $\mathrm{pH}$ play a critical role in achieving optimum efficiency of the system since both affect the availability of exchangeable reaction sites, the extent of stronger associations at higher $\mathrm{pH}$, and the degree of competition with the other cations in solution.

\section{CONCLUSIONS}

Cell surfaces of a mixed culture of sulphate-reducing bacteria with a high affinity for cationic nuclear fission products, $\mathrm{Sr}^{2+}$, $\mathrm{Co}^{2+}$, and $\mathrm{Cs}^{+}$, were determined to be predominantly comprised of carboxylate and phosphate sites (about $50 \%$ of the total concentration of all binding sites observed). The culture differed from previously studied cultures due to the presence of Gram(+ve) species with a higher concentration of polar functional groups $(-\mathrm{COOH})$ and $(-\mathrm{OH})$ on the cell walls. Approximately $68 \%$ of adsorbed metal species were exchangeable, demonstrating the feasibility of recovery of metals from wastewater streams using this culture. This observation is further supported by the observed predominance of weak interactions, which resulted in higher metal uptake at medium to low $\mathrm{pH}$ values below 7 . The decreased uptake of metals with increasing $\mathrm{pH}$ above 7 is attributed to competition for sites, with increasing dissociation of other metal complexes such as $\mathrm{Ca}^{2+}$ from sources within the medium resulting incompetitione for sites with $\mathrm{Sr}^{2+}, \mathrm{Co}^{2+}$ and $\mathrm{Cs}^{+}$.

\section{ACKNOWLEDGEMENTS}

The research was funded by the National Research Foundation (NRF) of South Africa, through Grant No. FA2007030400002 awarded to Prof EMN Chirwa of the University of Pretoria, and the South African Nuclear Human Asset Research Programme (SANHARP), through a scholarship bursary to the first author, N Ngwenya.

\section{REFERENCES}

AHMED I, AKIRA YOKOTA A, YAMAZOE A and FUJIWARA T (2007) Proposal of Lysinibacillus boronitolerans gen. nov. sp. nov., and transfer of Bacillus fusiformis to Lysinibacillus fusiformis comb. nov. and Bacillus sphaericus to Lysinibacillus sphaericus comb. nov. Int. J. Syst. Evol. Microbiol. 57 (5) 1117-1125.

AJLOUNI AMS (2007) Health consequences of nuclear fission products. J. Appl. Sci. Environ. Manage. 11 (3) 11-14.

ALLISON JD, BROWN DS and NOVO-GRADAC KJ (1991) MINTEQA2/PRODEFA2, a geochemical assessment model for environmental systems (Version 3.0), User's manual.
Environmental Research Laboratory, Office of Research and Development, U.S. Environmental Protection Agency, Washington, D.C.

ALMAGUER-CANTÚ V, MORALES-RAMOS LH and BALDERASRENTERÍA I (2011) Biosorption of lead (II) and cadmium (II) using Escherichia coli genetically engineered with mice metallothionein I. Water Sci. Technol. 63 (8) 1607-1613.

APELL H-J and DILLER A (2002) Do $\mathrm{H}^{+}$ions obscure electrogenic $\mathrm{Na}^{+}$ and $\mathrm{K}^{+}$binding in the $\mathrm{E}_{1}$ state of the $\mathrm{Na}, \mathrm{K}$-ATPase? FEBS Lett. 532 (2) 198-202.

BAES CF and MESMER RE (1976) The Hydrolysis of Cations. Wiley Science, New York.

BORROK DM and FEIN JB (2005) The impact of ionic strength on the adsorption of protons, $\mathrm{Pb}, \mathrm{Cd}$, and $\mathrm{Sr}$ onto the surface of Gram negative bacteria: testing non-electrostatic, diffuse, and triple-layer models. J. Colloid. Interface Sci. 286 (1) 110-126.

BUTLIN KR, ADAMS ME and THOMAS M (1949) The isolation and cultivation of sulphate-reducing bacteria. J. Gen. Microbiol. 3 (1) 46-59.

CHEN S, LIU X and DONG X (2005) Syntrophobacter sulfatireducens sp. nov., a novel syntrophic, propionate-oxidising bacterium isolated from UASB reactors. Int. J. Syst. Evol.Microbiol. 55 (3) 1319-1324.

CHIRWA EMN (2011) Development of biological treatment processes for the separation and recovery of radioactive wastes. In: Nash KL and Lumetta GJ (eds) Advanced Separation Techniques for Nuclear Fuel Reprocessing and Radioactive Waste Treatment. Woodhead Publishing, Cambridge. 436-472.

DAUGHNEY CJ, CHATELLIER X, CHAN A, KENWARD P, FORTIN D, SUTTLE CA and FOWLE DA (2004) Adsorption and precipitation of iron from seawater on a marine bacteriophage (PWH3A-P1). Mar. Chem. 91 (1) 101-115.

DE CARVALHO CCCR and FERNANDES P (2010) Production of metabolites as bacterial responses to the marine environment. Mar. Drugs 8 (3) 705-727.

DEWIERE L, BUGAI D, GRENIER C, KASHPAROV V and AHAMDACH N (2004) 90Sr migration to the geosphere from a waste burial in the Chernobyl Exclusion Zone. J. Environ. Radioact. 74 (1) 139-150.

DONATH E, WALTHER D, SHILOV VN, KNIPPEL E, BUDDE A, LOWACK K, HELM CA and MÖHWALD H (1997) Nonlinear hairy layer theory of electrophoretic fingerprinting applied to consecutive layer by layer polyelectrolyte adsorption onto charged polystyrene latex particles. Langmuir 13 (20) 5294-5305.

FEIN JB, BOILY J-F, YEE N, GORMAN-LEWIS D and TURNER BF (2005) Potentiometric titrations of Bacillus subtilis cells to low $\mathrm{pH}$ and comparison of modelling approaches, Geochim. Cosmochim. Acta 69 (5) 1123-1132.

GADD GM (2010) Metal, minerals and microbes: geomicrobiology and bioremediation. Microbiol. 156 (3) 609-643.

GOLDBERG S (1995) Adsorption models incorporated into chemical equilibrium models. In: Leoppert RH, Schwab AP and Goldberg S (eds) Chemical Equilibrium and Reaction Models. SSSA Special Publication 42. Soil Science Society of America, Madison, WI. 5. 75-95.

GREVE K, NIESEN E and LADEFOGEN O (2007) Evaluation of health hazards by exposure to strontium in drinking water. Toxicol. Lett. 172 S210.

HARJULA R and LEHTO J (1986) Effect of sodium and potassium ions on cesium absorption from nuclear power plant waste solutions on synthetic zeolites. Nucl. Chem. Waste Manage. 6 (2) 133-137.

HAAS JR, DICHRISTINA TJ and WADE R (2001) Thermodynamics of U(VI) sorption onto Shewanella putrifaciens. Chem. Geol. 180 (1) $33-54$.

JONÁŠ I and NORDÉN B (1974) Induced optical activity in $\mathrm{Co}\left(\mathrm{NH}_{3}\right)_{6}{ }_{6}^{3+}$ by outer-sphere association with chiral anions. Acta Chem. Scand. A 28 289-293.

JOO J-H, HASSAN SHA and OH S-E (2010) Comparative study of biosorption of $\mathrm{Zn}^{2+}$ by Pseudomonas aeruginosa and Bacillus cereus. Int. Biodeterior. Biodegrad. 64 (8) 734-741.

KUMAR R, SINGH S and SINGH OV (2007) Bioremediation of radionuclides: emerging technologies. OMICS 11 295-304. 
LIU M, DONG F, KANG W, SUN S, WEI H, ZHANG W, NIE X, GUO Y, HUANG T and LIU Y (2014) Biosorption of strontium from simulated nuclear wastewater by Scenedesmus spinosus under culture conditions: adsorption and bioaccumulation processes and models. Int. J. Environ. Res. Public Health 11 (6) 6099-6118.

MISRA S, SHARMA V and KUMAR SRIVASTAVA A (2014) Bacterial polysaccharides: an Overview. In: Ramawat KG and Mérillon JM (eds), Polysaccharides: Bioactivity and Biotechnology. Springer International Publishing, Cham (ZG), Switzerland. 1-24.

NGWENYA N and CHIRWA EMN (2010) Single and binary component sorption of the fission products $\mathrm{Sr}^{2+}, \mathrm{Cs}^{+}$and $\mathrm{Co}^{2+}$ from aqueous solutions onto sulphate reducing bacteria. Miner. Eng. 23 (6) 463-470.

NGWENYA BT, SURTHERLAND I and KENNEDY L (2003) Comparison of the acid-base behaviour and metal adsorption characteristics of a gram-negative bacterium with other strains. Appl. Geochem. 18 (4) 527-538.

NGWENYA N (2011) Bioremediation of metallic fission products in nuclear waste : biosorption and biorecovery. $\mathrm{PhD}$ thesis, University of Pretoria. URL: http://upetd.up.ac.za/thesis/available/ etd-10122011-151728.

OJEDA JJ, ROMERO-GONZALEZ ME, BACHMANN RT, EDYVEAN RGJ and BANWART SA (2008) Characterization of the cell surface and cell wall chemistry of drinking water bacteria by combining XPS, FTIR spectroscopy, modelling and potentiometric titrations. Langmuir 24 (8) 4032-4040.

PAGNANELLI F, BORNORONI L, MOSCARDINI E and TORO L (2006) Non-electrostatic surface complexation models for protons and lead(II) sorption onto single minerals and their mixture. Chemosphere 63 (7) 1063-1073.

POSTGATE JR (1984) The sulphate-reducing bacteria ( $\left.2^{\text {nd }} e d n\right)$. Cambridge University Press, London.

SOLECKI J (2006) Investigation of 85Sr adsorption in the presence of $\mathrm{Na}^{+}, \mathrm{K}^{+}$and $\mathrm{Cs}^{+}$on selected soils from different horizons. J. Radioanal. Nucl. Chem. 268 (2) 357-364.

TOURNEY J, NGWENYA BT, MOSSELMANS JWF, TETLEY L and COWIE GL (2008) The effect of Extracellular polymers (EPS) on the proton adsorption characteristics of the thermophile Bacillus licheniformis S-86. Chem. Geol. 247 (1) 1-15.

VIJAYARAGHAVAN K and YUN Y-S (2008) Bacterial biosorbents and biosorption. Biotechnol. Adv. 26 (3) 266-291.

WESTALL JC (1982) FITEQL, A computer program for determination of chemical equilibrium constants from experimental data. Report 82-02, Department of Chemistry. University of Oregon, Oregon, WA.

WOHL GR, CHETTLE DR, PEJOVIĆ-MILIĆ A, DRUCHOK C, WEBBER CE, ADACHI JD and BEATTIE KA (2013) Accumulation of bone strontium measured by in vivo XRF in rats supplemented with strontium citrate and strontium ranelate. Bone 52 (1) 63-69.

YEE N and FEIN JB (2001) Cd adsorption onto bacterial surfaces: a universal adsorption edge? Geochim. Cosmochim. Acta 65(13) 2037-2042.

ZOUBOULIS AI, LOUKIDOU MX and MATIS KA (2004) Biosorption of toxic metals from aqueous solutions by bacteria strains isolated from metal-polluted soils. Process Biochem. 39 (8) 909-916.

\section{SYMBOLS}

$C_{a} \quad$ molar concentration of acid

$C_{\mathrm{b}} \quad$ molar concentration of base

$C_{\text {tot }}$ total site concentration on bacterial cell surface

$F^{\text {tot }} \quad$ Faraday constant $\left(\mathrm{C} \cdot \mathrm{mol}_{\mathrm{c}}^{-1}\right)$

$k_{2} \quad$ second-order reaction rate constant $\left(T^{-1}\right)$

K zero charge/zero coverage constant

$K_{\text {as }} \quad$ stability constant

$K_{\text {int }}^{\text {as }} \quad$ intrinsic stability constant

$m_{\mathrm{b}} \quad$ concentration of SRB cells

$\mathrm{M}^{+} \quad$ target metal

$n_{\mathrm{II}} \quad$ number of chemical components

$n_{\mathrm{p}} \quad$ number of data points

$n_{\mathrm{u}}^{\mathrm{p}} \quad$ number of adjustable parameters

$q_{\mathrm{eq}} \quad$ equilibrium coefficient ( $\mathrm{g}$ metal ion.g biomass ${ }^{1}$ )

$\mathrm{R} \quad$ molar gas constant $\left(\mathrm{J} \cdot \mathrm{gmol}^{-1} \times \mathrm{K}^{-1}\right)$

R-A $\quad$ deprotonated bacterial surface site

R-AM metal site complex

$\sigma_{\text {av }} \quad$ average standard error

$S_{\mathrm{Y}} \quad$ default experimental error

$T \quad$ absolute temperature $\left({ }^{\circ} \mathrm{K}\right)$

$Y \quad$ error in the mass balance calculations (from the program FITMOD).

$\Psi \quad$ surface potential measured in volts (V)

$Z \quad$ charge of the adsorbing ion 